\title{
Phytosociology and taxonomic notes on some endemic-rich associations of the Naples Gulf
}

\author{
Giuliano Fanelli $^{1}$, Dario La Montagna ${ }^{1}$ (i) Fabio Attorre $^{1}$ (D), \\ Michele De Sanctis ${ }^{1}$ (i) \& Paola Masucci ${ }^{2}$
}

Key words: Chasmophyte, Endemic dolomite, Phytogeography, Phytosociology, Scrub, Southern Italy.

Ključne besede: hazmofit, endemiti na dolomitu, fitogeografija, fitosociologija, Scrub, južna Italija.

Corresponding author:

Dario La Montagna

E-mail:

dario.lamontagna.6@gmail.com

Received: 10. 6. 2021

Accepted: 30. 12. 2021

\begin{abstract}
The Gulf of Naples is an important centre of endemism, well known from the floristic point of view, but much less from the phytosociological one. In this paper we investigated the non-forest vegetation focusing on communities rich in endemics. We described two communities as new: Eryngio amethystini-Santolinetum neapolitanae for the garrigues on limestone, Globulario neapolitanae-Loniceretum stabianae for the vegetation on dolomitic rocks, both from the Lattari mountains, and we extend the area of Crithmo maritimi-Limonietum cumani for the vegetation on volcanic rocks and rarely on limestones along the coast, which was known for a few localities. The syntaxonomical position and the phytogeographical context of these communities are discussed. A few taxonomic notes are added on rare or interesting species retrieved in the course of the enquiry.

\section{Izvleček}

Neapeljski zaliv je pomembno središče endemizma, poznan zaradi flore, še bolj pa po rastlinskih združbah. V članku smo obravnavali negozdno vegetacijo, predvsem združbe, bogate z endemiti. Opisali smo dve novi asociaciji: Eryngio amethystiniSantolinetum neapolitanae za garigo na apnencu in Globulario neapolitanaeLoniceretum stabianae za vegetacijo na dolomitnem skalovju, ki uspevata na gorovju Lattari. Območje razširjenosti asociacije Crithmo maritimi-Limonietum cumani smo razširili na vegetacijo na vulkanskem skalovju in redko na apnencu ob obali, ki je bila do sedaj znana le z nekaj lokacijami. Obravnavali smo sintaksonomsko uvrstitev in fitogeografijo teh rastlinskih združb. Dodali smo nekaj taksonomskih opomb o redkih ali zanimivih vrstah, ki smo jih zabeležili v naši raziskavi.
\end{abstract}

1 Department of Environmental Biology, Sapienza University of Rome, Rome, Italy.

2 Centro Studi Interdisciplinari Gaiola onlus, AMP Parco Sommerso di Gaiola, Discesa Gaiola, Napoli, Italy. 


\section{Introduction}

The area of the Gulf of Naples and in particular its southern part, the Sorrento Peninsula, has since long attracted the attention of botanists for his rich and interesting flora. The explorations of several botanists including Tenore, Gussone, Lojacono and others (Del Guacchio et al., 2020) have recognized the strong floristic identity of this territory characterized by a high number of narrow range endemics. There are two main types of endemics, those related to the coast, both on volcanic rocks and on limestone, and the endemics of the garrigues and rocks of the mountain areas. Among the species thriving on the coast Centaurea cineraria subsp. sirenum, Centaurea deusta subsp. leucolepis, Limonium cumanum, Limonium tenoreanum, Seseli polyphyllum, can be mentioned. While in the Sorrento Peninsula and the small "Lattari" mountain range Bromopsis caprina, Centaurea tenorei, Globularia neapolitana, Lonicera stabiana, Santolina neapolitana can be found. Moreover, together with the high number of local endemics, several Italian endemics such as Helichrysum litoreum and Centaurea cineraria subsp. cineraria are occurring. These high levels of endemism led to the identification of distinct ecoregions (Blasi et al., 2018).

While the floristic knowledge of this area is quite good (SBI, 1952; De Natale et al., 2008; Blasi \& Biondi, 2017), the vegetation has still to be thoroughly investigated. A map of the series of vegetation exists (Blasi, 2010) but detailed phytosociological and syntaxonomical studies of the area are almost completely lacking (but see Masucci \& Simeone, 2006). A valuable paper on the forest vegetation recently appeared (Cancellieri et al., 2017) but they investigated only the area of Amalfi in Salerno administrative province. In order to fill this gap, we analysed the nonforest vegetation types rich in endemics of the Gulf of Naples. The material we collected is sometimes not very abundant, due to the rarity of the vegetation. Nonetheless we think that the survey of these communities is rather complete and deserve to be presented.

Moreover, during the study of these communities we collected rare and interesting species, on which we have made some taxonomic observations that we report below in the text in a separate paragraph.

\section{Material and methods}

\section{Study area}

The Gulf of Naples has an extension of $195 \mathrm{~km}$, between Mt. of Procida and "Punta Campanella". The area is mainly hilly with high cliffs along the coast. In the south a small mountain range occupy most of the Sorrento
Peninsula which closes the gulf and reaches the highest altitude at Mt. Sant'Angelo a Tre Pizzi (1444m). Another peak above $1000 \mathrm{~m}$ is Mt. Faito $(1131 \mathrm{~m})$. The dolomitic landscape of this mountain range is characterized by steep slopes and cliffs and is renowned worldwide for its scenic sightings.

The complex geology results from the Apennine orogenesis and the subsequent extensional phase that leaded to formation of volcanoes along the Tyrrhenian coast. These phases can be recognizable in the Sorrento Peninsula (an anti-Apennine thrust) and the volcanic complex of Vesuvio and Campi Flegrei (Casciello et al., 2006).

The differences between these two sides of the gulf lies on the lithology. In fact, the coastal line and the area of Posillipo are characterized by tuffaceous material and lapillus from the volcanic complex of "Campi Flegrei" forming the older deposit of Trentaremi tuff ring in the homonymous bay and the characteristic and younger stratigraphic unit of "Neapolitan Yellow Tuff” (Scarpati et al., 2013).

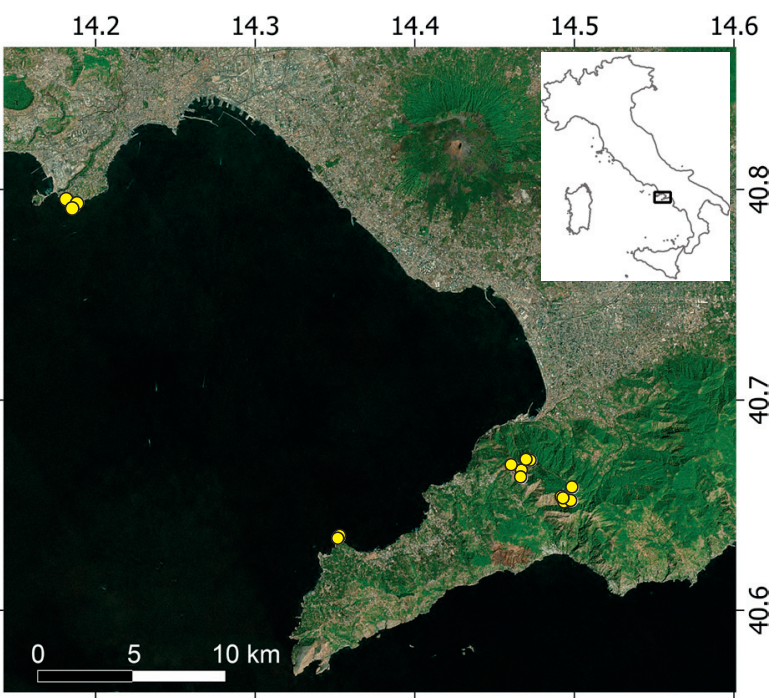

Figure 1: Map of the study site with localization of relevés.

Slika 1: Zemljevid obravnavanega območja z lokacijami vegetacijskih popisov.

On the other side the lithology is characterized by two main types. On the coastal line of Sorrento, the stratigraphic unit is represented by the "Campanian Ignimbrite" (Milia, 1998), that forms a characteristic crag and shows an influence of the super-syntheme "Flegreo-Ischitano" (ISPRA, 2014) formed by tuff and pyroclasts. Conversely in the inner area and on the heights, the lithology drastically changes, showing the carbonatic geological base that characterizes the peninsular Italy, with dolomites and micritic limestone formations dating back to the Cretaceous and Jurassic period (Iannace et al., 2008). 
The whole area can be referred to the Mediterranean macrobioclimate, but at higher altitude, like Mt. Faito and Mt. San Michele, a temperate thermotype and an
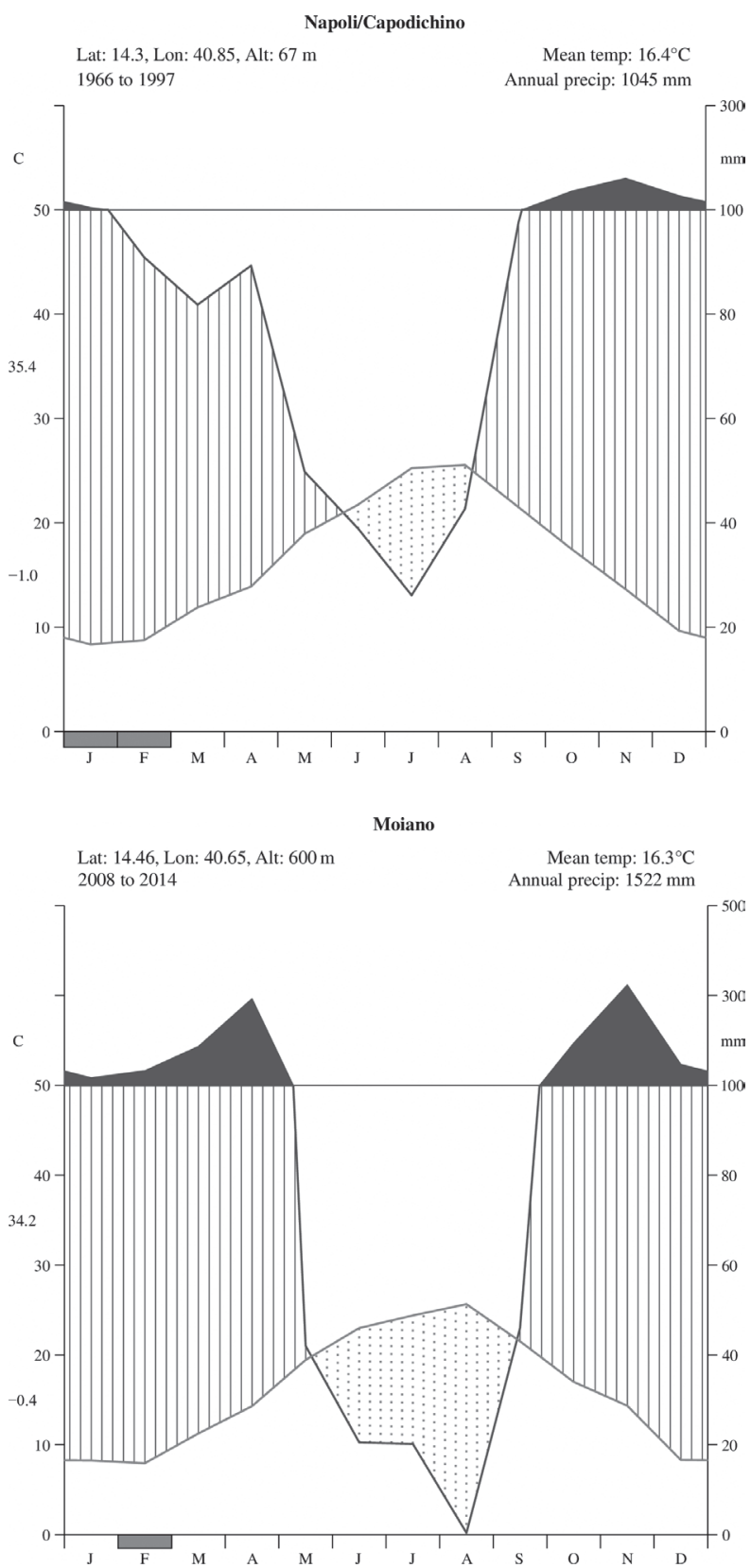

Figure 2: Climatic diagrams of two stations of the study site. We used bibliographic data (ISPRA, 2003) and data sets from the SCIA database (ISPRA, 2011) for a period of -30 years (normal climatic) for Naples and 7 years for Moiano. The elaboration and creation of the Walter and Lieth diagram were made with R package "climatol".

Slika 2: Klimatski diagram dveh postaj v obravnavanem območju. Uporabili smo objavljene podatke (ISPRA, 2003) in podatkovni niz iz baze SCIA (ISPRA, 2011) za obdobje -30 let (normalna klima) za Neapelj in 7 let za Moiano. Obdelavo in izdelavo diagrama po Walter in Lieth smo naredili v R paketu "climatol". upper humid ombrotype can be found (Pesaresi et al., 2017). On the contrary, the area of Posillipo, shows a lower mesomediterranean thermotype and a lower subhumid ombrotypes.

According to Blasi et al. (2018) the Gulf of Naples belongs to the Southern Tyrrhenian Section, but to different subsections: the area near Naples (with volcanic substrates) fits the Western Campania Subsection, while the carbonatic area of the Sorrento Peninsula can be referred to the Cilento Subsection.

The vegetation in both areas is generally anthropogenically influenced, especially in the surroundings of Naples where the urbanization led to the disappearance of several habitats (De Natale \& La Valva, 2000). The Mediterranean belt has almost disappeared and only small fragments of maquis with Pistacia lentiscus and other sclerophyllous species occurs. The supramediterranean belt in the Sorrento Peninsula is characterized mainly by secondary chestnut forest, but locally relics of the original oak and mixed forest dominated by Quercus cerris and Ostrya carpinifolia can still be found. Above $1000 \mathrm{~m}$ the mountain belt hosts a thermophilic beech forest (Cancellieri et al., 2017).

\section{Phytosociological survey}

In the summer 2020 we carried out 25 phytosociological relevés in selected vegetation types rich in endemics. Relevés were carried out according to Braun-Blanquet method (Westhoff \& van der Maarel, 1980) using the modified Braun-Blanquet scale of abundance (Barkman et al., 1964).

The phytosociological relevés have been carried out in the area of Mt. Faito and Mt. San Michele in the Sorrento Peninsula in an altitude range between $500-1100 \mathrm{~m}$ a.s.l., and on the coast of Sorrento and Posillipo, in particular in the marine protected area "Parco Sommerso di Gaiola”.

The table of relevés was arranged manually into three tables corresponding to well defined communities and the diagnostic species were chosen subjectively, by means of comparison with tables of similar vegetation in the literature. In the choice of diagnostic species, preference has been given to rare species of Sorrento Peninsula and neighbouring areas. Relevés will be deposited in the EVA database, the database of European vegetation (Chytrý et al., 2016).

The nomenclatural of the species and syntaxa, follow Bartolucci et al. (2018) checklist and Mucina et al. (2016) respectively. 


\section{Results and discussion}

\section{Community with Santolina neapolitana}

Santolina is a genus of shrubby Asteraceae with seven closely related species identified for Italy (Pignatti et al., 2017). Several species have been brought in cultivation blurring the original distribution. Nonetheless in the hills and mountains of the western Mediterranean basin many endemics can be found. Santolina neapolitana is a species endemic to the Campania region. In the Lattari Mts. it occurs with an extensive population from $600 \mathrm{~m}$ to $1100 \mathrm{~m}$ in the peaks of Mt. Faito and Mt. San Michele (Figure 3).

The floristic composition of this community above $1000 \mathrm{~m}$ in the mountain belt is dominated by chamaephytes and hemicryptophytes mainly on ridges. Below the community occurs in mosaic with therophytes such as Gastridium ventricosum, Trifolium scabrum, Daucus broteroi. At these altitudes, the chamaephytes are mainly restricted to rockier sites.
From the syntaxonomical point of view the community with Santolina neapolitana is characterized by two floristic pools. The first is represented by chamaephytes and small shrubs and can be referred to the alliance Cytiso spinescenti-Saturejon montanae (Pirone \& Tammaro, 1997). The second pool is characterized by hemicryptophytes of Festuco-Brometea Br.-Bl. et Tx. ex Soó 1947 even though the physiognomy suggests that the community with Santolina is a garrigue and not a grassland. Moreover, this community is well characterized not only by the endemic Santolina neapolitana but also by other rare or endemic species, such as Centaurea tenorei, endemic of Sorrento Peninsula and Galium lucidum subsp. bernardii which is restricted to Southern Italy. Although these species are hemicryptophytes, they clearly belong to the floristic composition of our association.

For this reason, we describe this community as Eryngio amethystini-Santolinetum neapolitanae ass. nov. hoc loco (holotypus relevé 11, Table 1). Eryngium amethystinum is not a character-species but is physiognomically important.

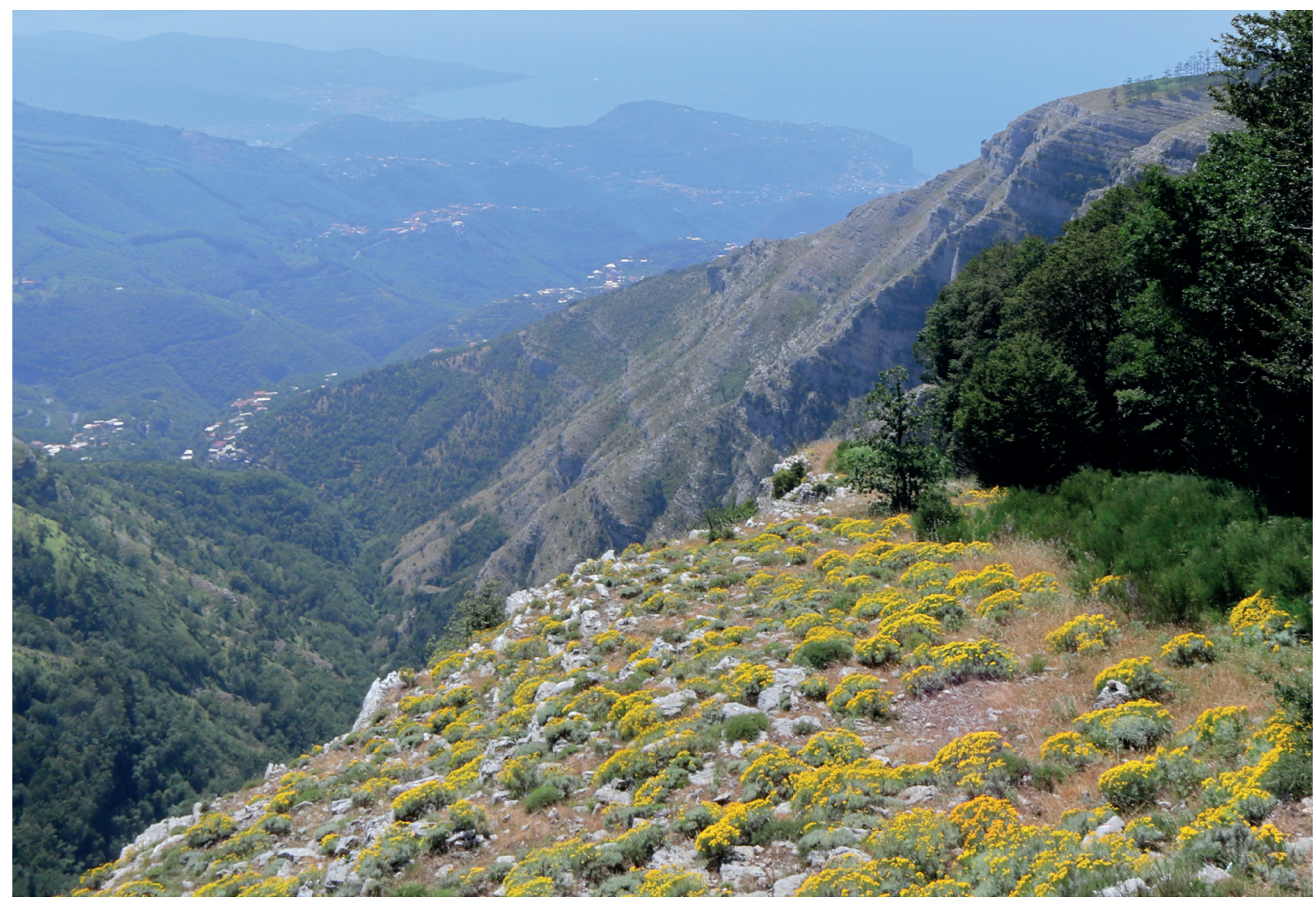

Figure 3: Garigue with Santolina neapolitana in Monte Sant'Angelo a Tre Pizzi. Slika 3: Gariga z vrsto Santolina neapolitana na Monte Sant'Angelo a Tre Pizzi. 
Table 1: Phytosociological table of Eryngio amethystini-Santolinetum neapolitanae ass. nova.

Tabela 1: Fitocenološka tabela asociacije Eryngio amethystini-Santolinetum neapolitanae ass. nova.

\begin{tabular}{|c|c|c|c|c|c|c|c|c|c|c|c|c|}
\hline Relevé N. & 1 & 2 & 3 & 4 & 5 & 6 & 7 & 8 & 9 & 10 & $11^{*}$ & \\
\hline Altitude (m a.s.l.) & 727 & 1032 & 1029 & 618 & 657 & 1038 & 1241 & 1156 & 1133 & 1130 & 1209 & \\
\hline Slope $\left(^{\circ}\right)$ & 5 & 5 & 30 & 90 & 90 & 15 & 10 & 70 & 5 & 10 & 20 & \\
\hline Exposure & S-SW & SW & $\mathrm{N}$ & SW & NW & $\mathrm{N}$ & S-SW & SE & $S$ & SE & S-SW & \\
\hline Plot size $\left(\mathrm{m}^{2}\right)$ & 3 & 30 & 20 & 25 & 40 & 30 & 40 & 20 & 10 & 10 & 25 & \\
\hline Total cover (\%) & 100 & 60 & 60 & 70 & 60 & 98 & 80 & 85 & 50 & 70 & 75 & \\
\hline Plot height $(\mathrm{cm})$ & 40 & 40 & 40 & & & 30 & 50 & 40 & 30 & 40 & 30 & \\
\hline \multicolumn{12}{|c|}{ Char Eryngio amethystini.-Santolinetum neapolitanae } & Freq. \\
\hline Santolina neapolitana & $2 \mathrm{a}$ & $2 b$ & $2 b$ & $2 b$ & + & 5 & 4 & 4 & $2 b$ & $2 \mathrm{a}$ & 4 & 100 \\
\hline \multicolumn{13}{|l|}{ Differentials of the association } \\
\hline Galium lucidum subsp. bernardii & + & & + & $2 \mathrm{a}$ & & & & + & & & & 36 \\
\hline Centaurea tenorei & & & & & & & & & 3 & + & & 18 \\
\hline \multicolumn{13}{|c|}{ Char Cityso-Saturejon montane, Ononido-Rosmarinetea } \\
\hline Helianthemum nummularium subsp. obscurum & & + & + & + & & + & + & + & & + & + & 73 \\
\hline Thapsia asclepium & $2 \mathrm{a}$ & & & + & & & & & & & & 18 \\
\hline Euphorbia spinosa & & & & & & & & & $2 \mathrm{a}$ & $2 b$ & & 18 \\
\hline Satureja montana & & + & + & & & & & & & & & 18 \\
\hline Asperula aristata subsp. scabra & & & & & + & & & 1 & & & & 18 \\
\hline Achillea ligustica & & & & & & + & & + & & & & 18 \\
\hline Dianthus longicaulis & & & + & + & & & & & & & & 18 \\
\hline Cerastium lacaitae & & & & + & & & & & & & & 9 \\
\hline Cytisus spinescens & & & & & & & & & & & + & 9 \\
\hline \multicolumn{13}{|l|}{ Char Festuco-Brometea } \\
\hline Petrorhagia saxifraga subsp. saxifraga & & + & + & & & + & + & + & + & & + & 64 \\
\hline Bromopsis erecta & & & + & & & & + & + & 1 & + & $2 \mathrm{a}$ & 55 \\
\hline Eryngium amethystinum & $\mathrm{r}$ & 1 & 1 & & & + & + & & & & + & 55 \\
\hline Allium sphaerocephalon & & & + & + & & + & & & & 1 & & 36 \\
\hline Koeleria macrantha & & + & 1 & & & + & & & & & 1 & 36 \\
\hline Festuca jeanpertii subsp. campana & & + & & & & + & & 1 & 1 & & & 36 \\
\hline Teucrium montanum & & & & & & & + & 1 & & & 1 & 27 \\
\hline Allium pallens & & + & 1 & & & & & & & & & 18 \\
\hline Bupleurum baldense & & + & + & & & & & & & & & 18 \\
\hline Sanguisorba minor subsp. minor & & & & + & & & + & & & & & 18 \\
\hline Orobanche lutea & & & & + & & & & & & & + & 18 \\
\hline Carlina corymbosa & & & & & & + & & & & + & & 18 \\
\hline Crepis lacera & & & & & & & & & & + & + & 18 \\
\hline Stachys recta & & & & + & & & & & & & & 9 \\
\hline Leontodon crispus & & & & + & & & & & & & & 9 \\
\hline Galium corrudifolium & & & & & + & & & & & & & 9 \\
\hline Teucrium chamaedrys & & & & & & + & & & & & & 9 \\
\hline Onobrychis viciifolia & & & & & & & & & & & + & 9 \\
\hline Knautia calycina & & & & & & & & + & & & & 9 \\
\hline \multicolumn{13}{|l|}{ Char Sedo-Scleranthetea } \\
\hline Petrosedum ochroleucum & & + & & + & & & + & + & + & & & 45 \\
\hline Sedum album & & + & + & & & & & & & & & 18 \\
\hline Ziziphora acinos & & + & & & & & & & & 1 & & 18 \\
\hline
\end{tabular}




\begin{tabular}{|c|c|c|c|c|c|c|c|c|c|c|c|c|}
\hline Relevé N. & 1 & 2 & 3 & 4 & 5 & 6 & 7 & 8 & 9 & 10 & $11^{*}$ & \\
\hline \multicolumn{13}{|l|}{ Companions } \\
\hline Avena barbata & + & + & & + & & 1 & & + & & & & 45 \\
\hline Briza maxima & + & + & & & & 1 & & + & & & & 36 \\
\hline Orlaya platycarpos & & & + & & & + & & + & + & & & 36 \\
\hline Trifolium scabrum & & + & + & & & & & & & + & & 27 \\
\hline Triticum neglectum & & + & + & & & + & & & & & & 27 \\
\hline Hypericum perforatum & 1 & + & & & & + & & & & & & 27 \\
\hline Crupina vulgaris & & + & + & & & + & & & & & & 27 \\
\hline Medicago minima & & & + & & & & & & + & + & & 27 \\
\hline Campanula fragilis subsp. fragilis & & & & + & + & & & & & & & 18 \\
\hline Trifolium campestre & + & & & & & + & & & & & & 18 \\
\hline Trifolium stellatum & & + & + & & & & & & & & & 18 \\
\hline Bromus hordeaceus subsp. molliformis & & & + & & & + & & & & & & 18 \\
\hline Lomelosia crenata & & & & & 3 & & & & & & + & 18 \\
\hline Centranthus ruber & & & & & + & & & & & & & 9 \\
\hline Anisantha rubens & & & + & & & & & & & & & 9 \\
\hline Coronilla valentina & & & & + & & & & & & & & 9 \\
\hline Daucus broteroi & + & & & & & & & & & & & 9 \\
\hline Sixalix atropurpurea & + & & & & & & & & & & & 9 \\
\hline Echium vulgare & 1 & & & & & & & & & & & 9 \\
\hline Brachypodium retusum & 3 & & & & & & & & & & & 9 \\
\hline Festuca danthonii & $\mathrm{r}$ & & & & & & & & & & & 9 \\
\hline Aira cupaniana & + & & & & & & & & & & & 9 \\
\hline Spartium junceum & & & & & + & & & & & & & 9 \\
\hline Poa bulbosa & & + & & & & & & & & & & 9 \\
\hline Fraxinus ornus & & & & & & 1 & & & & & & 9 \\
\hline Acer obtusatum & & & & & & 1 & & & & & & 9 \\
\hline Trifolium arvense & & & & & & + & & & & & & 9 \\
\hline Asphodelus macrocarpus & & & & & & & $\mathrm{r}$ & & & & & 9 \\
\hline Brachypodium distachyon & & & & & & & & & & + & & 9 \\
\hline
\end{tabular}

\section{Community with Lonicera stabiana and Globularia neapolitana}

On the rocky areas of Mt. Sant'Angelo, a chasmophytic community characterized by a high number of restricted endemics such as Lonicera stabiana, Globularia neapolitana, Bromopsis caprina can be found. Another very interesting species that occurs close to our relevés is Erica terminalis; this species is common in the eastern Mediterranean, where it builds extensive garrigues but is instead very rare in Italy where it occurs on shaded rocks (Pignatti et al., 2017).

The community is very distinct due to the presence of these rare endemics, and we described it as a new association Globulario neapolitanae-Loniceretum stabianae ass. nov. hoc loco (holotypus relevé 13, Table 2). We only have few relevés, but it was impossible to collect more material given the very restricted range of the association. Although the character-species of the association belong to different life form according to Raunkiær, they are very close. For instance, Globularia neapolitana has a shrubby habit quite different from that of the closely related Globularia cordifolia and Globularia meridionalis. Even Bromopsis caprina is quite different from a typical hemicryptophytes such as the closely related Bromopsis erecta and it is quite shrubby.

Santolina neapolitana, a shrubby species like the others of the association, seems to find its primary habitat in the Loniceretum stabianae where it presents also a slightly different more mesophytic phenotype. From Loniceretum stabianae this species invades successfully the garigues of the Santolinetum neapolitanae discussed previously.

In summary it is a community of endemic shrubby species. Species of other life forms occur in the relevés as transgressive from other communities as is frequent in rock communities. Inspecting the table, the idea is that the phanerophytic Lonicera stabiana invades different communities. It is quite the opposite since Lonicera stabiana has a very low competitive and dispersal power and could be "invaded" by species of other communities. 


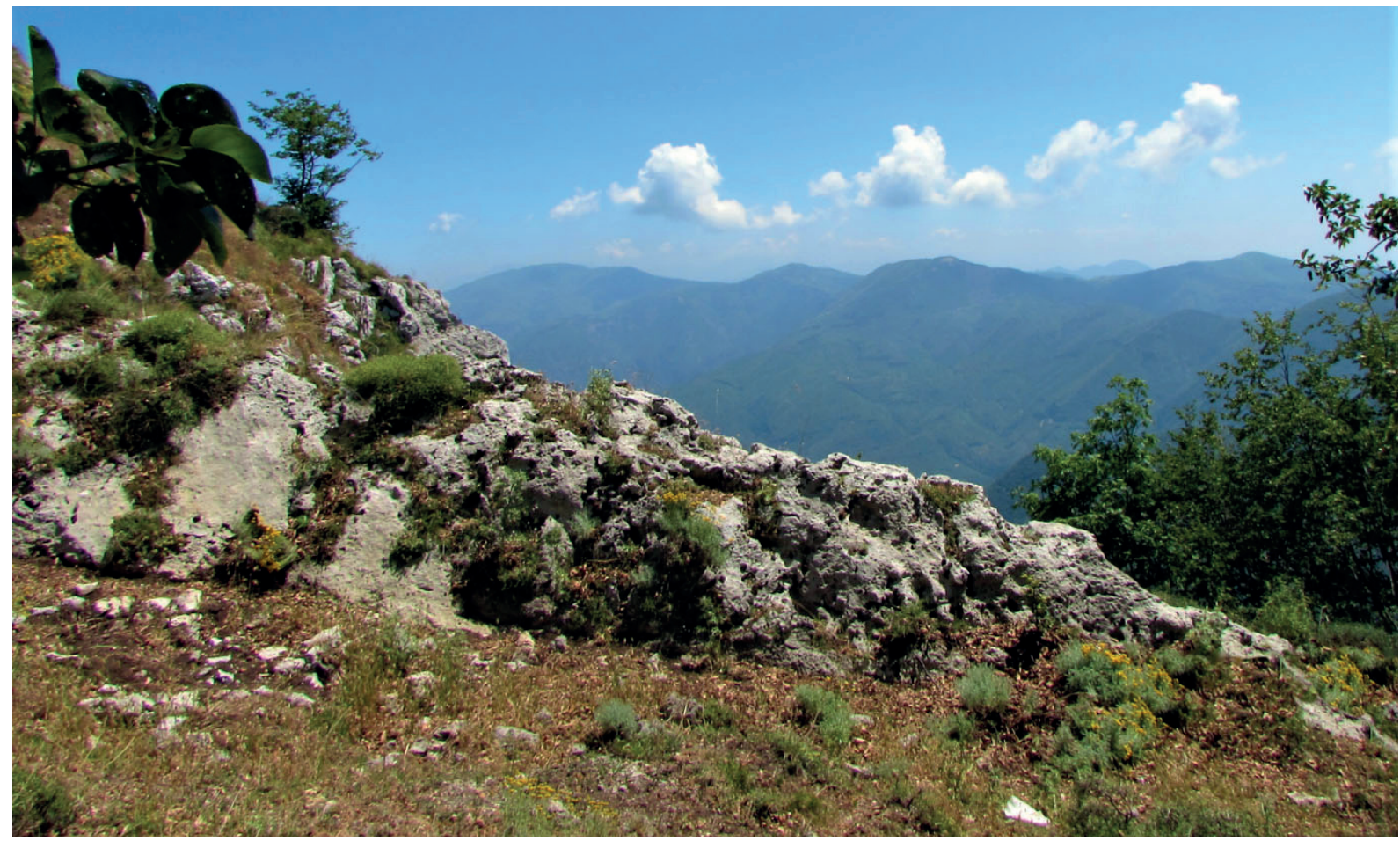

Concerning higher syntaxonomical units, the association clearly belong to the order Potentilletalia caulescentis Br.-Bl. in Br.-Bl. et Jenny 1926 of Asplenietea trichomanis (Br.-Bl. in Meier et Br.-Bl. 1934) Oberd. 1977, an order that encompasses the rocky vegetation on carbonates of the central and western Europe. Mucina et al. (2016) emphasized that Potentilletalia caulescentis is structurally heterogeneous since it includes associations dominated by hemicriptophytes and associations dominated by small shrubs. The possible separation of syntaxa dominated by chamaephytes and syntaxa dominated by shrubs requires further work (but see the nomenclatural revision in Terzi et al. (2017)). For the moment, based on the revision of Biondi et al. (1997), the closest alliance is Saxifragion australis Biondi et Ballelli ex S. Brullo 1984, described for the central and southern Apennines. However only one characteristic species of this alliance is present, Edraianthus graminifolius, while many Apennines endemics such as Campanula tanfanii and Saxifraga porophylla subsp. porophylla are absent. Moreover, the floristic pool of the Sorrento Peninsula is quite distinct from that of the rest of the Apennines and represents a distinct biogeographical province. Another difference is in the substrate. The associations of Saxifragion australis generally occur on limestone whereas our association is related to dolomites, which probably drive a completely different ecology from the vegetation growing on calcareous rocks. Saxifragion australis is an alliance of hemicriptophytes, whereas one of the most striking characters of the Loniceretum stabianae is that it is dominated by small shrubs such as Lonicera stabiana.

\begin{tabular}{lccccc}
\hline Relevé N. & 12 & $13^{*}$ & 14 & \\
\hline Altitude (m a.s.l.) & 1168 & 1160 & 1157 & \\
Slope $\left({ }^{\circ}\right)$ & 90 & 90 & 90 & \\
Exposure & $\mathrm{S}$ & $\mathrm{SW}$ & $\mathrm{SW}$ & \\
Plot size $\left(\mathrm{m}^{2}\right)$ & 30 & 20 & 15 & \\
Total cover (\%) & 15 & 35 & 10 & \\
\hline Char Globulario neapolitanae-Loniceretum & & & Freq. \\
stabianae nova & & & & \\
Lonicera stabiana & + & $2 \mathrm{a}$ & 1 & 100 \\
Globularia neapolitana & 1 & + & + & 100 \\
Santolina neapolitana & + & & 1 & 67 \\
Campanula fragilis subsp. fragilis & + & 1 & & 67 \\
Sesleria juncifolia subsp. juncifolia & + & & + & 67 \\
Bromopsis caprina & $2 \mathrm{~m}$ & 1 & & 67 \\
Char Saxifragion australis & & & & \\
Edraianthus graminifolius & & & + & 33 \\
Companions & & & & \\
Asperula aristata subsp. scabra & & + & & 33 \\
Galium lucidum subsp. bernardii & + & & & 33 \\
Leontodon crispus & + & & & 33 \\
Lomelosia crenata & & + & & 33 \\
\hline
\end{tabular}




\section{Community with Limonium cumanum}

Limonium cumanum is endemic to the Gulf of Naples. It is locally abundant but lacks from many areas. Differently from many other species of Limonium, this grows usually at some distance from the sea, and therefore it comes in close contact with the vegetation dominated by Helichrysum litoreum which is very important in the study area. This situation maybe is due to landslides which are very frequent in the volcanic rocks where this species usually occurs or maybe to certain intolerance to sea waves.

The composition of the community with Limonium cumanum is very similar to those of Crithmo-Staticion Molinier 1934 (e.g. Crithmo-Limonietum remotispiculi, see Corbetta et al. 2000) with Crithmum maritimum, Helichrysum litoreum, etc. and is distinct only in the identity of the Limonium species. Bartolo et al. (1989) described a Crithmo maritimi-Limonietum cumani Bartolo, Brullo \& Signorello 1989 from limestones in Capri and Sorrento. However, Limonium cumanum grows also frequently on volcanic tuffs and actually this species was described from this type of rock (Vallariello et al., 2016). Our relevés extend considerably the range of the association. We observe a slight differentiation of our relevés from those of Bartolo et al. (1989) especially for the presence of Jacobaea maritima subsp. bicolor in our relevés. Maybe the populations on tuffs represent a distinct subassociation, but we refrain for the moment from a formal description.

The community is common but is threatened by the anthropogenic influence and the invasion of the allochtonous Carpobrotus acinaciformis.

Table 3: Phytosociological table of Chritmo maritimi-Limonietum cumani Bartolo, Brullo \& Signorello 1989.

Tabela 3: Fitocenološka tabela asociacije Chritmo maritimi-Limonietum cumani Bartolo, Brullo \& Signorello 1989.

\begin{tabular}{|c|c|c|c|c|c|c|c|c|c|c|c|c|}
\hline Relevé N. & 15 & 16 & 17 & 18 & 19 & 20 & 21 & 22 & 23 & 24 & 25 & \\
\hline Altitude (m a.s.l.) & 20 & 16 & 25 & 3 & 8 & 7 & 7 & 6 & 6 & 7 & & \\
\hline Slope $\left(^{\circ}\right)$ & 90 & 20 & 90 & 90 & 80 & 80 & 90 & 80 & 90 & 90 & 90 & \\
\hline Exposure & S-SE & $\mathrm{E}$ & $\mathrm{NE}$ & $\mathrm{E}$ & $\mathrm{E}$ & $\mathrm{E}$ & W & SE & SE & $\mathrm{NE}$ & NW & \\
\hline Plot size $\left(\mathrm{m}^{2}\right)$ & 5 & 5 & 3 & 3 & 5 & 4 & 8 & 10 & 10 & 4 & 6 & \\
\hline Total cover (\%) & 70 & 100 & 80 & 70 & 40 & 60 & 80 & 60 & 100 & 10 & 20 & \\
\hline Plot height $(\mathrm{cm})$ & & 60 & & & 40 & 40 & 20 & 30 & 20 & 20 & 40 & \\
\hline \multicolumn{12}{|c|}{ Char Chritmo-Limonietum cumani Bartolo, Brullo \& Signorello 1989} & Freq. \\
\hline Limonium cumanum & 5 & + & 1 & 1 & 1 & + & 1 & $2 \mathrm{a}$ & 1 & 1 & 1 & 100 \\
\hline \multicolumn{13}{|c|}{ Char Chritmo-Staticeon, Chritmo-Staticetea } \\
\hline Helichrysum litoreum & & 5 & 4 & 3 & + & & + & $2 b$ & & & $2 \mathrm{~b}$ & 64 \\
\hline Crithmum maritimum & + & & & + & 1 & & $2 b$ & & + & + & $2 \mathrm{a}$ & 64 \\
\hline Jacobaea maritima subsp. bicolor & & & & & & & & + & & + & & 18 \\
\hline Medicago arborea & & & & & + & & & & & & & 9 \\
\hline Allium commutatum & & & & & & & + & & & & & 9 \\
\hline \multicolumn{13}{|l|}{ Companions } \\
\hline Carpobrotus acinaciformis & & & & & & $2 \mathrm{a}$ & 4 & $2 \mathrm{~b}$ & 4 & + & & 45 \\
\hline Dactylis glomerata subsp. hispanica & & & + & + & & & & & & & + & 27 \\
\hline Artemisia campestris subsp. variabilis & & & & & $2 \mathrm{~b}$ & 3 & & & & & + & 27 \\
\hline Asparagus acutifolius & & + & + & & & & & & & & & 18 \\
\hline Dittrichia viscosa & & & + & & & & & & & & & 9 \\
\hline Sixalix atropurpurea & & & + & & & & & & & & & 9 \\
\hline Daucus carota & & & + & & & & & & & & & 9 \\
\hline Pistacia lentiscus & & & 1 & & & & & & & & & 9 \\
\hline
\end{tabular}

\section{Taxonomical notes}

Aim of these notes is to present some observations on the variability of a few rare species that has been overlooked or taken marginally into account in the literature. In recent years several nomenclatural papers have appeared giving useful information about these species, but the de- scriptions that can be found in the reference texts often do not represent the full variability. We refrain from formal proposal because there is dramatic need of molecular studies on the flora of Southern Italy.

Santolina neapolitana: We observed a modest variation in the sizes of the capitula. In many cases the capitula were smaller $(6 \mathrm{~mm})$ than the range sizes mentioned in 
Pignatti et al. (2017), especially in individuals growing on rocks. This character can be included in the variability of the species and maybe can change during the development of the flowers. We observed moreover individuals with glaucous and green leaves as often reported in literature (Del Guacchio et al., 2020) but these two types of leaves could occur on the same individual and are therefore unimportant taxonomically.

Lonicera stabiana: is a species of the group of Lonicera etrusca from which it is distinct from the colour of the berry and the different habitat. Nonetheless it must be stressed that in central Campania there are a few divergent populations of Lonicera etrusca. For instance, both in the Picentini Mts. and in the Sorrento Peninsula at lower altitudes populations of Lonicera etrusca are present with shrubby habit and atypical inflorescence which are perhaps intermediate between typical Lonicera etrusca and Lonicera stabiana (Herbarium Fanelli in RO). Also, near Naples populations of Lonicera etrusca with atypical features are frequent. Central Campania is possibly an area of intensive speciation of the group of Lonicera etrusca.

Globularia neapolitana: belongs to a difficult group that has been variously interpreted. Del Guacchio et al. (2020) and Innangi et al. (2020) consider Globularia neapolitana as a xeromorphic aspect of Globularia cordifolia in the Mediterranean climate, whereas Pignatti et al. (2017) consider the species perfectly distinct. In our opinion the morphology of the leaves suggests a close relationship of Globularia neapolitana with Globularia cordifolia than with Globularia meridionalis. The shrubby habit is quite peculiar and is probably not an adaptation to the Mediterranean climate but to the dolomite substrate. We think that the three species are distinct enough to deserve recognition at the species level. The problem could be solved only with the support of molecular analyses.

Sesleria juncifolia subsp. juncifolia: The group of Sesleria juncifolia is very difficult (Di Pietro et al., 2013; Đenader et al., 2020). According to Di Pietro (2007) our material on the Sesleria found in Loniceretum stabianae keys out clearly in Sesleria juncifolia subsp. juncifolia (Figure 5). Nonetheless the material is different from the populations in central

Apennine, because the inflorescences are smaller, and the leaves are more robust. Ubaldi (2006) described a Sesleria apennina subsp. cylindrifolia var. circeana (Bég.) Ubaldi which inhabits similar habitats and can be related to the material observed by us. The problem deserves more study.

Bromopsis caprina: is circumscribed in two very different ways in the two editions of the Flora d'Italia of Pignatti (1982, 2017). In the edition of 1982, Bromopsis caprina is mainly distinct for the indumentum of the stem

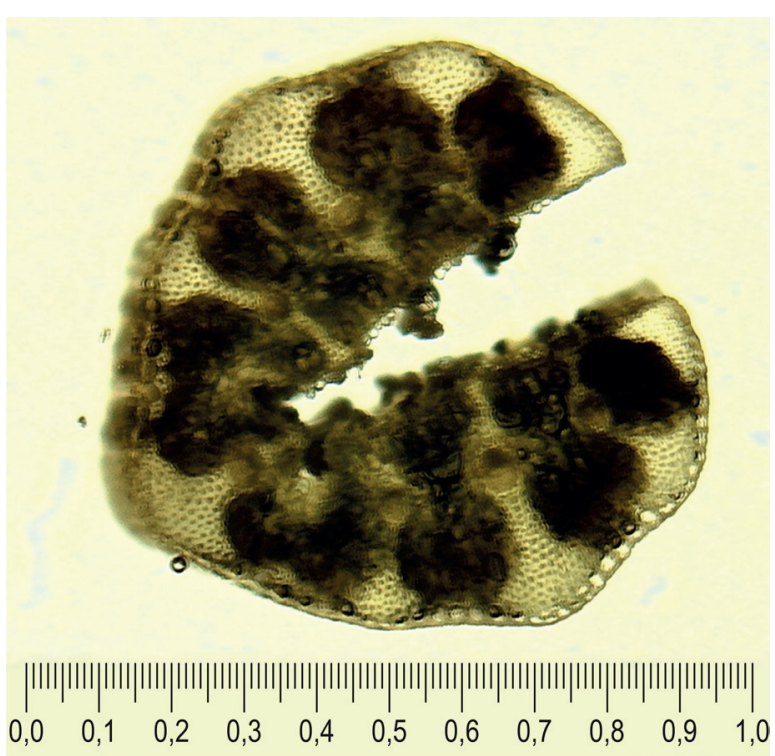

Figure 5: Leaf section of Sesleria juncifolia subsp. juncifolia at 5x magnification.

Slika 5: Prerez lista vrste vrste Sesleria juncifolia subsp. juncifolia pri 5x povečavi.

and is a widespread species weakly differentiated from Bromopsis erecta widespread in dry grasslands in Southern Italy, hence the alliance Cytiso spinescentis-Bromion caprini Bonin in Barbero et Bonin 1969. In the edition of 2017 Bromopsis caprina is a rare species of rocks, probably endemic to the Gulf of Naples, mainly distinct for the shape of the spike and the spikelets. After examination of the type there is no doubt that the correct definition is the latter (JSTOR Global Plants, 2020). In our study we found both forms of Bromopsis: Bromopsis caprina sensu Pignatti (1982) is widespread in the Santolinetum neapolitanae, whereas typical Bromopsis caprina sensu Pignatti et al. (2017) occurs rarely on the rocks of Loniceretum stabianae.

Limonium cumanum: is very variable but can easily be distinguished by the pubescent leaves. It is usually indicated on volcanic rocks, but it can grow equally on limestone. For instance, one of our relevés from Sorrento was carried out on limestone (relevé 18, Table 3).

\section{Conclusions}

The three associations described in this paper are striking since they present an astounding level of endemism not different from that of some insular ecosystems. They add to the already gathered information in emphasizing the distinctiveness of the phytogeographical sector of the Gulf of Naples. In the recent literature (Blasi et al., 2018) the 
Gulf of Naples is assigned to different ecoregions mainly on the base of the distinct history and geology of tuffs near the coast and the limestones of the Sorrento Peninsula. Here we discard the obvious differences between the different substrates and concentrate on the high rate of (neo)endemism in the whole Gulf of Naples.

Mountains near the sea are often sites of high endemism (Sierra Nevada in Spain, Durmitor in Montenegro, Çika in Albania, Apuan Alps in Italy). The reason of this high level of endemism is the peculiar climate of mountains near the sea, with their clouds belt originating from the winds blowing from the sea, allowing the persistence of tertiary relics confined to warm and moist climate (Mahmutaj et al., 2014). The origin of endemics in the Gulf of Naples seems quite different from that of Durmitor or Apuane Alps. In the latter paleoendemics dominate, whereas the endemics of Sorrento Peninsula and Gulf of Naples are of a different kind, being closely related to more common species often widespread in the Apennines: Globularia neapolitana is related to Globularia cordifolia, Lonicera stabiana to Lonicera etrusca and Centaurea tenorei to Centaurea ambigua. In other terms it seems that the Gulf of Naples is not an area of conservation of relict species. but rather a center of differentiation and speciation of neoendemics. For instance, Limonium which is notoriously fragmented into several narrowly range species presents here an exceptional diversity at least for Italy, with three species in a small area. Also, Centaurea cineraria has been shown to be highly diverse in the area from a molecular point of view (Hilpold et al., 2011).

The reason why the Gulf of Naples seems to represent a centre of differentiation is open to speculations, but a role is probably played by the diversity of substrata. Along the coast, volcanic rocks are presents with chemistry typical to the Neapolitan magmatic province. Probably this chemistry played a role in the differentiation of the Limonium species and of other seacoast species. On the Lattari Mts., in the areas richest in endemics, the rapid speciation that seems to occur is possibly driven by the necessity to adapt to the peculiar chemistry of the dolomitic rocks. Differently from serpentines rocks, the role of dolomitic substrata in the evolution and ecology of plants is poorly known (Mota et al., 2008) but is well established for instance in Pinus spp. (Barbéro et al., 1998) and in a few phytosociological syntaxa which are related to dolomites (Mucina et al., 2016). In particular, in the Baetic province of the Southern Iberian Peninsula, scrubby vegetation exists with an extraordinarily high number of endemics (Mota et al. 2017). The Sorrento Peninsula, with its unusual concentration of narrow endemics, maybe represents on a smaller scale an analogous case. The new association (Globulario neapolitanae-Loniceretum stabianae) recog- nises the singularity of the dolomitic habitat of this area. Ecophysiological and phylogenetic research in this topic could be very rewarding - a few studies have highlighted that dolomitic soil alter the water balance of tree seedlings (Pröll et al., 2016), but little is known about the effects of dolomite on plant life.

Another explanation of the high number of endemic species for the Gulf of Naples, is the possible isolation during periods of marine transgression (Santangelo et al., 2017; Caiazzo et al., 2006). Southern Italy was repeatedly fragmented into small islands during the Tertiary and Quaternary. Fragmentation has been demonstrated to play a role in the genetic differentiation of many species of vertebrates (Canestrelli et al., 2010). The hypothesis of isolation is not mutually exclusive with the selective role of substratum since both could have played a role at the same time. Nonetheless edaphic hypothesis is more consistent with the presence of a few endemics of the Sorrento Peninsula in the Picentini Mountains which probably were not isolated from the mainland (Santolina neapolitana, Globularia neapolitana).

From the point of view of conservation, the three communities here described occupy a very small area, in particular Loniceretum stabianae; nonetheless they do not seem to be threatened since they occupy marginal unexploited habitats. Only the status of Limonietum cumani raises some concerns due to the high human impact and biological invasions. For instance, a small station of $\mathrm{Li}$ monium cumanum on the beach of Gaiola, which was recorded in 2019 has already disappeared due to touristic exploitation. Limonietum cumani represents Habitats 1240 and Lonicereteum stabianae Habitat 8210 sensu EU (European Commission 2013) and thus they deserve particular attention and protection.

\section{Acknowledgements}

We would like to thank Donatella Magri, Alessandra Celant and all the staff of the Paleobotany and Palynology laboratory for kindly granting us the use of the microscope for Sesleria section, the Research and Disclosure Centre "AMP Parco Sommerso di Gaiola" for the access to the protected area and for the help in the surveys with the kayak, to Gerardo Longo for help us during fieldwork, and finally to two anonymous referees for the suggestions that greatly improved the manuscript.

Giuliano Fanelli (D) https://orcid.org/0000-0002-3143-1212

Dario La Montagna (D) https://orcid.org/0000-0002-7124-493X

Fabio Attorre (D) https://orcid.org/0000-0002-7744-2195

Michele De Sanctis (D) https://orcid.org/0000-0002-7280-6199 


\section{References}

Barbéro, M., Loisel, R., Quézel, P., Richardson, D.M., \& Romane, F. (1998). Pines of the Mediterranean Basin. In D.M., Richardson (Ed.), Ecology and Biogeography of Pinus (pp. 153-170). Cambridge University Press.

Barkman, J.J., Doing, H., \& Segal, S. (1964). Kritische Bemerkungen und Vorschläge zur quantitativen Vegetationsanalyse. Acta Botanica Neerlandica, 13, 394-419.

Bartolo, G., Brullo, S., \& Signorello, P. (1989). La classe CrithmoLimonietea nella penisola italiana. Colloques phytosociologiques, 19, $55-81$.

Bartolucci, F., Peruzzi, L., Galasso, G., Albano, A., Alessandrini, A., Ardenghi, N.M.G., Astuti, G., Bacchetta, G., Ballelli, S., Banfi, E., Barberis, G., Bernardo, L., Bouvet, D., Bovio, M., Cecchi, L., Di Pietro, R., Domina, G., Fascetti, S., Fenu, G., Festi, F., Foggi, B., Gallo, L., Gottschlich, G., Gubellini, L., Iamonico, D., Iberite, M., Jiménez-Mejías, P., Lattanzi, E., Marchetti, D., Martinetto, E., Masin, R.R., Medagli, P., Passalacqua, N.G., Peccenini, S., Pennesi, R., Pierini, B., Poldini, L., Prosser, F., Raimondo, F.M., Roma-Marzio, F., Rosati, L., Santangelo, A., Scoppola, A., Scortegagna, S., Selvaggi, A., Selvi, F., Soldano, A., Stinca, A., Wagensommer, R.P., Wilhalm, T., \& Conti, F. (2018). An updated checklist of the vascular flora native to Italy. Plant Biosystems, 152(2), 179-303. https://doi.org/10.1080/1126 3504.2017 .1419996

Blasi, C. (2010). La vegetazione d'Italia. Palombi Editori.

Blasi, C., \& Biondi, E. (2017). La flora in Italia. Sapienza Università Editrice.

Blasi, C., Capotorti, G., Copiz, R., Guida, D., Mollo, B., Smiraglia, D., \& Zavattero, L. (2018). Terrestrial Ecoregions of Italy: Map and Explanatory notes. Global Map S.r.l.

Caiazzo, C., Ascione, A., \& Cinque, A. (2006). Late TertiaryQuaternary tectonics of the Southern Apennines (Italy): new evidences from the Tyrrhenian slope. Tectonophysics, 421(1-2), 23-51. https://doi. org/10.1016/j.tecto.2006.04.011

Cancellieri, L., Caneva, G., \& Cutini, M. (2017). Phytosociology and ecology of the Mediterranean forests ecosystems in the Amalfi Coast (Monti Lattari, Italy). Rendiconti Lincei, 28, 651-671. https://doi. org/10.1007/s12210-017-0635-x

Canestrelli, D., Aloise, G., Cecchetti, S., \& Nascetti, G. (2010). Birth of a hotspot of intraspecific genetic diversity: notes from the underground. Molecular Ecology, 19(24), 5432-5451. https://doi. org/10.1111/j.1365-294X.2010.04900.x

Casciello, E., Cesarano, M., \& Pappone, G. (2006). Extensional detachment faulting on the Tyrrhenian margin of the southern Apennines contractional belt (Italy). Journal of the Geological Society, 163(4), 617-629. https://doi.org/10.1144/0016-764905-054

Chytrý, M., Hennekens, S.M., Jiménez-Alfaro, B., Knollová, I., Dengler, J., Jansen, F., Landucci, F., Schaminée, J.H., Aćić, S., Agrillo, E., Ambarli, D., Angelini, P., Apostolova, I., Attorre, F., Berg, C., Bergmeier, E., Biurrun, I., Botta-Dukát, Z., Brisse, H., Campos, J.A., Carlón, L., Čarni, A., Casella, L., Csiky, J., Ćušterevska, R., Dajić Stevanović, Z., Danihelka, J., deBie, E., deRuffray, P., deSanctis, M., Dickoré, W.B., Dimopoulos, P., Dubyna, D., Dziuba, T., Ejrnaes, R., Ermakov, N., Ewald, J., Fanelli, G., Fernández-González, F., Fitzpatrick, Ú., Font, X., García-Mijangos, I., Gavilán, R. G., Golub, V., Guarino, R., Haveman, R., Indreica, A., Işıı Gürsoy, D., Jandt, U.,
Janssen, J. A. M., Jiroušek, M., Kącki, Z., Kavgaci, A., Kleikamp, M., Kolomiychuk, V., Krstivojević Ćuk, M., Krstonošić, D., Kuzemko, A., Lenoir, J., Lysenko, T., Marcenò, C., Martynenko, V., Michalcová, D., Moeslund, J. E., Onyshchenko, V., Pedashenko, H., Pérez-Haase, A., Peterka, T., Prokhorov, V., Rašomavičius, V., Rodríguez-Rojo, M. P., Rodwell, J. S., Rogova, T., Ruprecht, E., Rūsina, S., Seidler, G., Šibík, J., Šilc, U., Škvorc, Ž., Sopotlieva, D., Stančić, Z., Svenning, J.-C., Swacha, G., Tsiripidis, I., Turtureanu, P. D., Uğurlu, E., Uogintas, D., Valachovič, M., Vashenyak, Y., Vassilev, K., Venanzoni, R., Virtanen, R., Weekes, L., Willner, W., Wohlgemuth, T., \& Yamalov, S. (2016). European Vegetation Archive (EVA): an integrated database of European vegetation plots. Applied Vegetation Science, 19(1), 173-180. https://doi.org/10.1111/avsc.12191

Corbetta, F., Frattaroli, A.R., Ciaschetti, G., \& Pirone, G. (2000). Some aspects of the chasmophytic vegetation in the Cilento - Vallo di Diano National Park (Campania - Italy). Acta Botanica Croatica, 59(1), $43-53$.

De Natale, A., Di Nuzzo, F., \& Crescenzi, E. (2008). Note di floristica per la Penisola Sorrentina, il Massiccio del Matese e specie notevoli per la Campania. Informatore Botanico Italiano, 40(2), 243-248.

De Natale, A., \& La Valva, V. (2000). La flora di Napoli: i quartieri della città. Webbia, 54(2), 271-375. https://doi.org/10.1080/0083779 2.2000 .10670681

Del Guacchio, E., Innangi, M., Giacò, A., Peruzzi, L., \& Caputo, P. (2020). Taxa endemic to Campania (southern Italy): nomenclatural and taxonomic notes. Phytotaxa, 449(3), 217-231. https://doi. org/10.11646/phytotaxa.449.3.2

Đenader, T., Lakušić, D., \& Kuzmanović, N. (2020). Variability of leaf blade anatomical traits in the Sesleria juncifolia complex (Poaceae) on the Balkan Peninsula. Phytotaxa, 442(3), 138-152.

Di Pietro, R. (2007). Taxonomic features of Sesleria calabrica (Poaceae), a neglected species from Southern Italy. Folia Geobotanica, 42, 289-313. https://doi.org/10.1007/BF02806468

Di Pietro, R., D'amato, G., \& Trombetta, B. (2005). Karyology and distribution of Sesleria tenuifolia complex (Poaceae) in the Italian Peninsula. Nordic Journal of Botany, 23, 615-623. https://doi. org/10.1111/j.1756-1051.2003.tb00442.x

Di Pietro, R., Kuzmanović, N., Iamonico, D., Pignotti, L., Barina, Z., Lakušić, D., \& Alegro, A. (2013). Typification of names in the Sesleria juncifolia species complex (Poaceae). Phytotaxa, 152(1), 18-32. doi:10.11646/phytotaxa.152.1.2

European Commission. (2013). Interpretation Manual of European Union Habitats, version EUR 28.

Hilpold, A., Schönswetter, P., Susanna, A., Garcia-Jacas, N., \& Vilatersana, R. (2011). Evolution of the central Mediterranean Centaurea cineraria group (Asteraceae): Evidence for relatively recent, allopatric diversification following transoceanic seed dispersal. Taxon, 6O(2), 528-538. https://doi.org/10.1002/tax.602019

Iannace, A., Galluccio, L., Guerriero, V., Mazzoli, S., Parente, M., \& Vitale, S. (2008). Dolomites within the Mesozoic carbonates of Southern Apennines (Italy): genetic models and reservoir implications. Rendiconti Online Società Geologica Italiana, 2, 109-114.

Innangi, M., Friščić, M., Hazler Pilepić, K., Danise, T., Conti, F., Bartolucci, F., Fioretto, A., \& Peruzzi, L. (2020). Explaining Intricate Morphometric Variability with Environmental Predictors: The Case of Globularia cordifolia Species Complex. Plants, 9(3), 314. https://doi. org/10.3390/plants9030314 
ISPRA. (2003). Progetto Annali. Retrieved September 1, 2020, from https:/www.isprambiente.gov.it/it/progetti/cartella-progetti-in-corso/ acque-interne-e-marino-costiere-1/progetto-annali

ISPRA. (2011). SCIA - Sistema nazionale per la raccolta, l'elaborazione e la diffusione di dati Climatologici di Interesse Ambientale. Retrieved September 1, 2020, from http://www.scia.isprambiente.it/ wwwrootscia/Home_new.htm

ISPRA. (2014). Carta Geologica d'Italia alla scala 1: 50.000 - CARG project (Foglio 466, Sorrento). Retrieved September 1, 2020, from https://www.isprambiente.gov.it/Media/carg/index.html

JSTOR Global Plants. (2020). JSTOR Global Plants Database. Retrieved September 1, 2020, from https://plants.jstor.org (accessed September 2020).

Mahmutaj, E., Hoda, P., \& Shuka, L. (2014). Rare plants and their conservation status in Tomorri National Park. Journal of Endocytobiosis and Cell Research, 25, 27-32.

Masucci, P., \& Simeone, M. (2006, September 27-29). Indagine florovegetazionale sulla costa emersa del Parco Sommerso di Gaiola (Golfo di Napoli). $101^{\circ}$ Congresso della Società Botanica Italiana, Caserta, Italy.

Milia, A. (1998). Le unità piroclastiche tardo-quaternarie nel Golfo di Napoli. Geografia Fisica e Dinamica Quaternaria, 21, 147-153.

Mota, J.F., Medina-Cazorla, J.M., Navarro, F.B., Pérez-García, F.J., Pérez-Latorre, A., Sánchez-Gómez, P., Torres, J.A., Benavente, A., Blanca, G., Gil, C., Lorite, J., \& Merlo, M.E. (2008). Dolomite flora of the Baetic Ranges glades (South Spain). Flora, 203, 359-375. https://doi.org/10.1016/j.flora.2007.06.006

Mota, J.F., Garrido-Becerra, J.A., Merlo, M.E., Medina-Cazorla, J.M. \& Sánchez-Gómez, P. (2017). The Edaphism: Gypsum, Dolomite and Serpentine Flora and Vegetation. In J., Loidi (Ed.), The Vegetation of the Iberian Peninsula, Volume 2 (pp. 277-354). Springer.

Mucina, L., Bültmann, H., Dierßen, K., Theurillat, J.-P., Raus, T., Čarni, A., Šumberová, K., Willner, W., Dengler, J., Gavilán García, R., Chytrý, M., Hájek, M., Di Pietro, R., Iakushenko, D., Pallas, J., Daniëls, F.J.A., Bergmeier, E., Guerra, A.S., Ermakov, N., Valachovič, M., Schaminée, J.H.J., Lysenko, T., Didukh, Y.P., Pignatti, S., Rodwell, J.S., Capelo, J., Weber, H.E., Solomeshch, A., Dimopoulos, P., Aguiar, C., Hennekens, S.M., \& Tichý, L. (2016): Vegetation of Europe: hierarchical floristic classification system of vascular plant, bryophyte, lichen, and algal communities. Applied Vegetation Science, 19(1), 3-264. https://doi.org/10.1111/avsc.12257

Pignatti, S. (1982). Flora d'Italia (Vol. 1-3). Edagricole.

Pignatti, S., Guarino, R., \& La Rosa, M. (2017). Flora d'Italia (Vol. 1-4). Edagricole-New Business Media.

Pirone, G., Ciaschetti, G., Di Martino, L., Di Cecco, V., \& Frattaroli, A.R. (2014). Contributo alla conoscenza delle garighe collinari e submontane dell'Appennino Centrale. Micologia e Vegetazione Mediterranea, 29(1), 75-92.

Pirone, G., \& Tammaro, F. (1997). The hilly calciophilous garigues in Abruzzo (Central Apennines, Italy). Fitosociologia, 32, 73-90.

Pröll, G., Hietz, P., Delaney, C.M., \& Katzensteiner, K. (2016). Substrate influences ecophysiological performance of tree seedlings. Tree Physiology, 36, 39-53. https://doi.org/10.1093/treephys/tpv104
Santangelo, N., Romano, P., Ascione, A., \& Ermolli, E. R. (2017). Quaternary evolution of the Southern Apennines coastal plains: A review. Geologica Carpathica, 68(1), 43-56. https://doi.org/10.1515/ geoca-2017-0004

SBI. (1952). Escursione Sociale nel Cilento e nella Penisola Sorrentina (30 Maggio - 3 Giugno 1952). Giornale botanico italiano, 59(2-4), 441-584. http://dx.doi.org/10.1080/11263505209431546

Scarpati, C., Perrotta, A., Lepore, S., \& Calvert, A. (2013). Eruptive history of Neapolitan volcanoes: constraints from 40Ar-39Ar dating. Geological Magazine, 150(3), 412-425. https://doi.org/10.1017/ S0016756812000854

Terzi, M., Jasprica, N., \& Caković, D. (2017). Xerothermic chasmophytic vegetation of the central Mediterranean Basin: a nomenclatural revision. Phytocoenologia, 47(4), 365-383. https://doi. org/10.1127/phyto/2017/0185

Ubaldi, D. (2006). Contributo alla tassonomia di Sesleria apennina Ujhelyi (Liliopsida Poales Poaceae). Quaderno di Studi e Notizie di Storia Naturale della Romagna, 22, 65-74.

Vallariello, R., Iamonico, D., \& Del Guacchio, E. (2016). Typification of three accepted names in Limonium (Plumbaginaceae). Phytotaxa, 263(2), 131-138. http://dx.doi.org/10.11646/phytotaxa.263.2.5

Westhoff, V., \& van der Maarel, E. (1980). The Braun-Blanquet approach. In R. H., Whittaker (Ed.), Classification of plant communities (pp. 287-399). W Junk 


\section{Appendix 1 Syntaxonomical scheme}

Asplenietea trichomanis (Br.-Bl. in Meier et Br.-Bl. 1934) Oberd. 1977

Potentilletalia caulescentis Br.-Bl. in Br.-Bl. et Jenny 1926

Saxifragion australis Biondi \& Ballelli ex Brullo 1984

Globulario neapolitanae-Loniceretum stabianae ass. nova

Festuco hystricis-Ononidetea striatae Rivas-Mart. et al. 2002

Erysimo-Jurineetalia bocconei S. Brullo 1984

Cytiso spinescentis-Saturejion montanae Pirone et Tammaro 1997

Eryngio amethystini-Santolinetum neapolitanae ass. nova

Crithmo-Staticetea Br.-Bl. in Br.-Bl. et al. 1952

Crithmo-Staticion Molinier 1934

Chritmo maritimi-Limonietum cumani Bartolo, Brullo \& Signorello 1989

\section{Appendix 2 \\ Locality and date of the relevés in Tables}

Stationary data are written in order: number of relevés, reference municipality, locality, WGS84 coordinates, altitude, date, and possible notes.

Rel. 1: Vico Equense, road to Mt. Faito, 4040.08' N; 14²7.58' E, 730m a.s.l., 08/07/2020.

Rel. 2-3: Vico Equense, Mt. Faito, $40^{\circ} 40.21^{\prime}$ N; $14^{\circ} 28.16^{\prime}$ E, $1030 \mathrm{~m}$ a.s.l., 08/07/2020.

Rel. 4: Vico Equense, road to Mt. Faito, 40³9.71' N; 14²7.95' E, 620m a.s.l., 08/07/2020.

Rel. 5: Vico Equense, road to Mt. Faito, 4039.91' N; 14²7.95' E, 660m a.s.l., 09/07/2020, cliff along the road.

Rel. 6: Vico Equense, Mt. Faito, 4040.21' N; 14²8.30' E, 1030m a.s.l., 09/07/2020, glade among pine trees.

Rel. 7: Vico Equense, road to S. Michele sanctuary, 40³9.43' N; $14^{\circ} 29.86^{\prime}$ E, $1240 \mathrm{~m}$ a.s.l., 09/07/2020.

Rel. 8: Vico Equense, towards Mt. S. Michele on 308 path, 40³9.15' N; 14²9.50' E, 1160m a.s.l., 09/07/2020.

Rel. 9-10: Vico Equense, towards Mt. S. Michele on 308 path, $40^{\circ} 39.06^{\prime}$ N; $1^{\circ} 29.61^{\prime}$ E, $1130 \mathrm{~m}$ a.s.l., 09/07/2020, scarp slope calcareous steps.

Rel. 11: Vico Equense, towards Mt. S. Michele on 308 path, 40³9.05' N; 14²9.83' E, 1210m a.s.l., 09/07/2020.

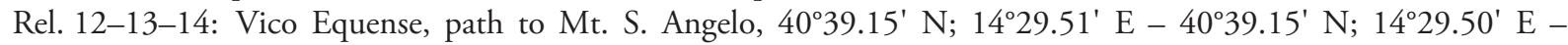
$40^{\circ} 39.11^{\prime} \mathrm{N}$; $14^{\circ} 29.53^{\prime} \mathrm{E}, 1170 \mathrm{~m} ; 1160 \mathrm{~m} ; 1160 \mathrm{~m}$ a.s.l., 09/07/2020, on cliffs.

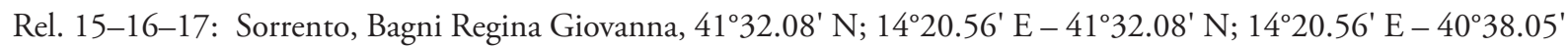
$\mathrm{N} ; 14^{\circ} 21.10^{\prime} \mathrm{E}, 20 \mathrm{~m} ; 15 \mathrm{~m} ; 25 \mathrm{~m}$ a.s.l., 09/07/2020, on the ruins of the Roman villae.

Rel. 18: Sorrento, Bagni Regina Giovanna, $40^{\circ} 37.98^{\prime} \mathrm{N} ; 1^{\circ} 21.05^{\prime}$ E, $5 \mathrm{~m}$ a.s.l., 09/07/2020, calcareous cliff.

Rel. 19-20-21: Napoli, Trentaremi bay, $40^{\circ} 47.70^{\prime} \mathrm{N} ; 4^{\circ} 10.91^{\prime} \mathrm{E}-40^{\circ} 47.68^{\prime} \mathrm{N} ; 1^{\circ} 10.91^{\prime} \mathrm{E}-40^{\circ} 47.71^{\prime} \mathrm{N}$; $14^{\circ} 10.90^{\prime}$ E, $10 \mathrm{~m}$ a.s.l., 25/08/2020, on cliff of "Tufo di Trentaremi".

Rel. 22-23: Napoli, Posillipo, 4047.51' N; $14^{\circ} 11.15^{\prime}$ E $-40^{\circ} 47.53^{\prime}$ N; $14^{\circ} 11.18^{\prime}$ E, $5 \mathrm{~m}$ a.s.l., 25/08/2020, on cliff of "Tufo Giallo Napoletano".

Rel. 24: Napoli, Gaiola, 4047.51' N; 14¹1.20' E, $10 \mathrm{~m}$ a.s.l., 25/08/2020, on cliff of "Tufo Giallo Napoletano".

Rel. 25: Napoli, Marechiaro, 4047.61' N; 14¹1.31' E, 5m a.s.l., 25/08/2020, on cliff of "Tufo Giallo Napoletano". 


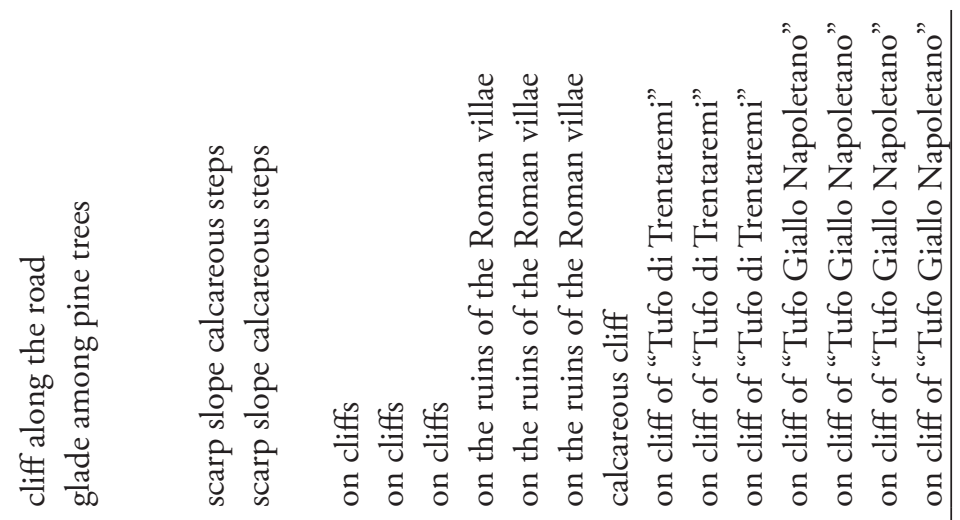

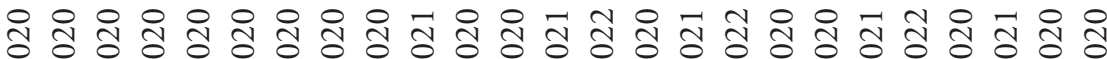

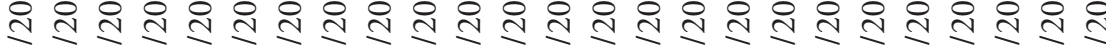

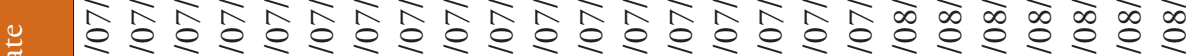

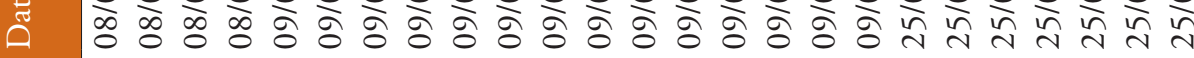

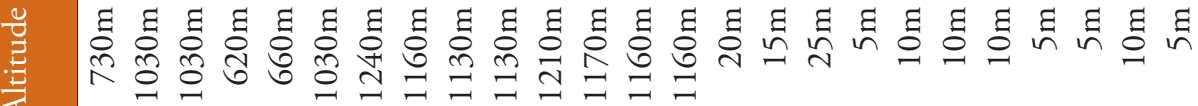

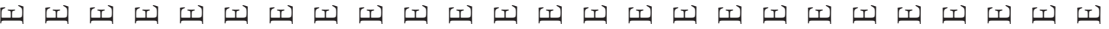

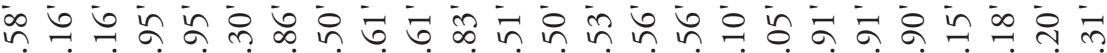
ปิ $\infty^{\infty} \hat{\sim}$ ปิ 孛 $\ddot{z} \ddot{z} \ddot{z} \ddot{z} \ddot{z} \ddot{z} \ddot{z} \ddot{z} \ddot{z} \ddot{z} \ddot{z} \ddot{z} \ddot{z} \ddot{z} \ddot{z} \ddot{z} \ddot{z} \ddot{z} \ddot{z} \ddot{z} \ddot{z} \ddot{z} \ddot{z} \ddot{z} \ddot{z}$

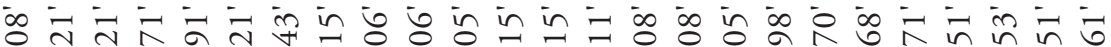

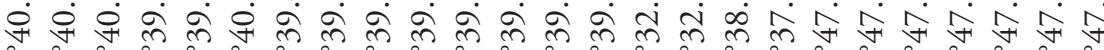

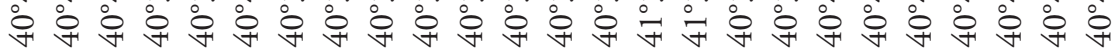

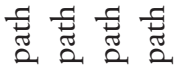
$\infty$

Эี ซี ธี ธี

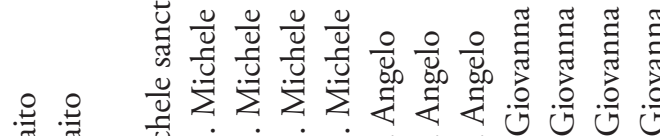

.

मتं

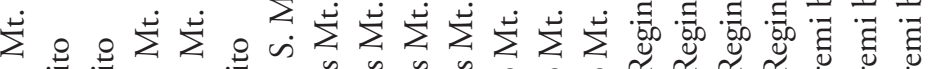
유ำ

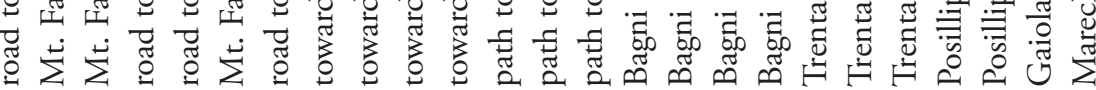
我 